\title{
Productivity and Protein Content in Barley Variety Grains in Northern Trans-Ural Region
}

\author{
Anatoly Yu. Pershakov \\ $\mathrm{PhD}$ student of the Department of Technology, Storage and \\ Processing of Crop Production \\ FSBEI HE Northern Trans-Ural SAU \\ Tyumen, Russia \\ pershakov.93@mail.ru
}

\author{
Victor K. Yakovlev \\ $\mathrm{PhD}$ student of the Department of Technology, Storage and \\ Processing of Crop Production \\ FSBEI HE Northern Trans-Ural SAU \\ Tyumen, Russia \\ kachestvo.17@mail.ru
}

\author{
Raisa I. Belkina \\ professor of the Department of Technology, \\ Storage and Processing of Crop Production \\ FSBEI HE Northern Trans-Ural SAU \\ Tyumen, Russia \\ raisa-medvedko@mail.ru
}

\begin{abstract}
The study was conducted in 2014-2016 in the northern forest-steppe area of Tyumen region. During the study of malting barley variety in two mineral fertilizer grounds the most productive grades were Omsky 85 and Beatrice. Their productivity in enhanced fertilizing ground made 5.98 and 5.84 t/ha respectively. The protein content in grains of the studied grades satisfied the GOST requirements for malting barley. The treatment of seeds and plants of barley grades with microfertilizers provided for their productivity growth. The Acha grade showed the maximum productivity when seeds were treated with Gidromix microfertilizers (4.55 t/ha), the Abalak grade - when seeds were treated with Gidromix and plants with Master complex up to the booting stage $(4.72 \mathrm{t} / \mathrm{ha})$. The use of microfertilizers ensured substantial increase of protein yield per unit area. As a result of studying the influence of barley seed treatment with fungicides and growth regulators it was found that the Abalak grade was more receptive than the Acha grade. The Acha grade showed the maximum productivity when seeds were treated with Lamador fungicide and Rostok stimulator $4.50 \mathrm{t} / \mathrm{ha}$, and the Abalak grade - when seeds were treated with Mival-Agro stimulator $\mathbf{- 4 . 6 0} \mathrm{t} / \mathrm{ha}$. The protein content in barley grains was quite high $-\mathbf{1 3 . 2 - 1 4 . 7 \%}$, which meets the $P$ 539002010 GOST requirements to feeding barley of the first class.
\end{abstract}

Keywords-barley, grades, productivity, microfertilizers, grain protein, protein yield per unit area.

\section{INTRODUCTION}

Barley occupies significant areas in the world only falling behind three grain crops: wheat, corn and rice. The gross yield of barley grains is used for forage. According to its nutritive value, barley exceeds corn and wheat since it is rich in more balanced amino-acid proteins. This advantage makes it possible to use barley seeds to feed all animals, especially pigs $[1,2]$.

Barley seeds is a valuable raw material for the brewing industry. It is used for malting. In the Northern Trans-Ural region the most limiting factor deteriorating the quality of malting barley varieties with regard to their compliance to the current GOST requirements is the germinating ability. According to the existing state standard, the quality of malt received from recognized Acha and Chelyabinsky 99 grades was within the range of requirements of the second class. The protein content of the Acha grade varied in agroclimatic zones of the area from 11.2 to $12.3 \%$ and of the Chelyabinsky 99 from 11.7 to $13.2 \%[3,4]$.

Grade is one of the most significant element of the grain production technology. The scientists of the Northern TransUral region are concerned with the creation of new grades of barley for various applications [5-9].

There is a need to develop efficient technologies aimed to intensify the growth and development of plants in order to ensure the best productivity and quality of barley grades. Fertilizers are considered the most important elements of technology affecting the productivity of grain crops. Besides, it is very important to study the response to the level of mineral nutrition, considering that the reaction of certain grades may differ considerably [10].

Alongside with macrofertilizers the technologies include the treatment of seeds and vegetative plants with microfertilizers. Such approaches contribute to the increase in chlorophyll content in plant leaves, enhance photosynthesis, and finally increase the productivity and quality of grains. The micronutrients forming microfertilizers ensure the increase of proteins, carbohydrates, amino acids, vitamins and other necessary substances. Under the influence of micronutrients the content of proteins, carbohydrates, amino acids, vitamins in plants increases. Microfertilizers (Gidromix, Master special, etc.) are produced as chelates or organic compounds. In this way, they are highly soluble in water, which ensures their high digestibility by plants. Copper, zinc, boron, and molybdenum being part part of microfertilizers represent a particular value 
for summer grain crops [11]. The efficiency of microfertilizers can be high in case of their complex use: treatment of seeds and foliar dressing [12].

The use of microfertilizers for summer wheat in Tyumen region showed that the most efficient treatment of seeds is treatment with the Gidromix complex and the treatment of plants with the Master special microfertilizer [13].

The complex treatment of seeds with disinfectants and growth regulators is considered a perspective element of technology positively influencing the growth and development of grain crops and their productivity in general. They ensure protection against infections and stimulate early growth of plants [14-16].

Purpose of the study: to study the productivity and protein content of barley grains treated with elements of cultivation technology in the conditions of the northern forest-steppe area of Tyumen region.

\section{SUBJECTS AND METHODS}

The study was conducted in 2014-2016 in the northern forest-steppe area of Tyumen region on a test field of the Northern Trans-Ural State Agricultural University. The soil of the test field contained leached chernozem with hard loam according to its particle size distribution. According to its chemical composition, the surface soil is characterized by the average humus content, average content of phosphorus, potassium and low content of nitrogen, subacidic reaction of soil solution.

The paper presents the results of three experiments that utilized various barley cultivation technologies.

Experiment 1. Influence of mineral fertilizers on productivity and quality of malting barley variety grains. The experiment covered such grades as Jana, Beatrice, Baltika, Peydzhaz, Omsky 85. According to their brewing properties, the Baltika and Peydzhaz grades were identified by M.V. Gubanov and were included in the study as the best collection samples of the All-Union Research Institute of Plant Breeding. The recognized Acha grade, malting and valuable in terms of quality, was taken as the standard. The grades were sowed in two mineral grounds: moderate (NPK - productivity $3 \mathrm{t} / \mathrm{ha}$ ) and enhanced (NPK - productivity $4 \mathrm{t} / \mathrm{ha}$ ). The precursor annual grass (pea-oat mixture).

Experiment 2. Influence of treatment of seeds and plants with microfertilizers on productivity and quality of barley seeds. The experiment included the following: 1. Control (water treatment of seeds). 2. Treatment of seeds with Gidromix, $100 \mathrm{~g}$ per ton of seeds. 3. Treatment of seeds with Gidromix, $100 \mathrm{~g} / \mathrm{t}+$ Master top dressing, $1 \mathrm{~kg} / \mathrm{ha}$ up to the booting stage. 4 . Treatment of seeds with Gidromix, $100 \mathrm{~g} / \mathrm{t}+$ Master top dressing, $1 \mathrm{~kg} / \mathrm{ha}$ up to the earing stage. 5 . Treatment of seeds with Gidromix + Master top dressing, 1 $\mathrm{kg} / \mathrm{ha}$ up to the booting and earing stages. The study included the recognized barley grades - Acha and Abalak. The precursor - winter crops. Mineral fertilizers (NPK) were applied in the amount of $4 \mathrm{t} / \mathrm{ha}$ per grain productivity.
Experiment 3. Influence of seed treatment with fungicides and growth regulators on productivity and quality of barley seeds. The experiment implied the treatment of seeds with fungicides and growth regulators: 1 . Control (water treatment of seeds). 2. Lamador Pro $(0.21 / t)$. 3. Rostok $(0.51 / t) .4$. Mival-Agro $(5 \mathrm{~g} / \mathrm{t})$. 5. Lamador Pro $(0.2 \mathrm{l} / \mathrm{t})+\operatorname{Rostok}(0.5 \mathrm{l} / \mathrm{t})$. 6. Lamador Pro $(0.2 \mathrm{l} / \mathrm{t})+$ Mival-Agro $(5 \mathrm{~g} / \mathrm{t})$. The study included Acha and Abalak grades. The precursor - annual grass (pea-oat mixture). Mineral fertilizers (NPK) were applied in the amount of $4 \mathrm{t} / \mathrm{ha}$ per grain productivity.

The experiments, observations and records were made via the technique of the State Committee for the Testing of New Varieties of Agricultural Plants. Grain protein content was determined by the Kjeldahl's method.

\section{RESULTS}

Weather conditions of the 2014 vegetative period were marked by increased rainfalls in July. The distinctive feature of 2015 was high mean daily temperature in comparison with the mean annual data in May and June, which slightly reduced in July and August. The amount of rainfalls slightly differed from the standard. In 2016 the temperature in May, June and August was above the mean annual values, rainfalls were uneven with the majority of them noted in the second decade of July. Thus, it is possible to consider that the conditions of growth and development of barley grades in the years of study were quite favorable and positively affected their productivity. According to experiment 1 , the productivity of malting barley varieties throughout the years of study made on average 4.51$5.78 \mathrm{t} / \mathrm{ha}$ at moderate amount of fertilizers, at enhanced amount - 4.44-5.98 t/ha (Fig. 1). The highest additional yield was recorded for Omsky 85: at moderate amount of fertilizers - $0.73 \mathrm{t} / \mathrm{ha}$, at enhanced amount $-0.49 \mathrm{t} / \mathrm{ha}$ and for the Beatrice grade: $0.50 \mathrm{t} / \mathrm{ha}$ and $0.35 \mathrm{t} / \mathrm{ha}$ respectively.

According to GOST requirements, the protein content in malting barley varieties shall not exceed $12 \%$. The grain of the studied grades corresponded to this level (Tab. 1). The protein content in standard-grade grain at moderate amount of fertilizers made $9.93 \%$, for other grades it varied from 8.62 to $9.53 \%$. The enhanced amount of fertilizers contributed to the increase in protein content: it reached $12.3 \%$ for the standardgrade grain and $9.8-11.6 \%$ for the studied grades. The enhanced amount of fertilizers was quite positive and resulted in the increase in protein content for all grades on average by $1.5 \%$ in comparison with the moderate amount.

The Peydzhaz grade formed slightly higher productivity than the standard - at moderate amount it made $0.36 \mathrm{t} / \mathrm{ha}$, at enganced $-0.27 \mathrm{t} / \mathrm{ha}$. The response to enhanced amount was demonstrated by the Acha standard grade - productivity was increased by $0.44 \mathrm{t} / \mathrm{ha}$, as well as the Peydzhaz $(+0.35 \mathrm{t} / \mathrm{ha})$ and the Beatrice $(+0.29 \mathrm{t} / \mathrm{ha})$. Thus, Omsky 85 and Beatrice grades were at the top in terms of productivity. At moderate amount the productivity of these grades reached 5.78 and 5.55 $\mathrm{t} / \mathrm{ha}$, at enhanced -5.98 and $5.84 \mathrm{t} / \mathrm{ha}$ respectively. 


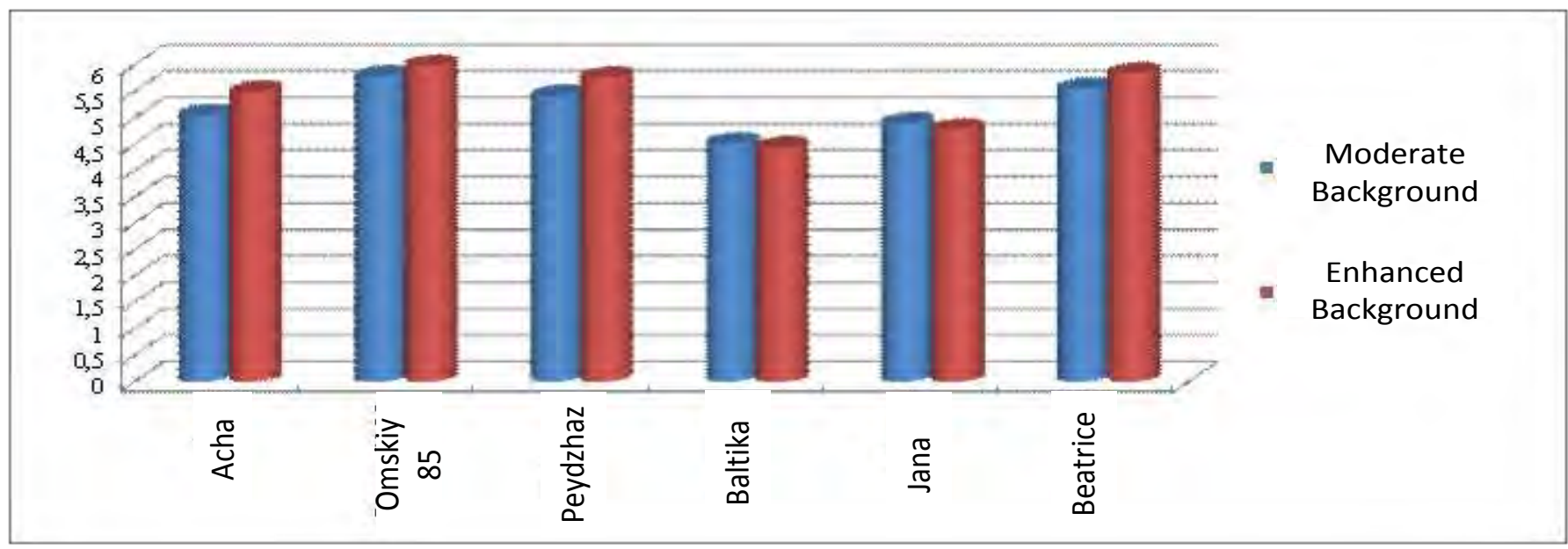

Fig. 1. Productivity of malting barley variety, t/ha (2014-2016)

According to GOST requirements, the protein content of malting barley varieties shall not exceed $12 \%$. The grain of the studied grades corresponded to this level (Tab. 1). The protein content in standard-grade grain at moderate amount of fertilizers made $9.93 \%$, for other grades it varied from 8.62 to $9.53 \%$. The enhanced amount of fertilizers contributed to the increase in protein content: it reached $12.3 \%$ for the standardgrade grain and $9.8-11.6 \%$ for the studied grades. The enhanced amount of fertilizers was quite positive and resulted in the increase in protein content for all grades on average by $1.5 \%$ in comparison with moderate amount.

The carrying capacity of the studied barley grades does not belong to the main features of their assessment, at the same time, it is advisable to compare grades against the complex indicator - protein yield per unit area. The Beatrice - 529 $\mathrm{kg} / \mathrm{ha}$, Acha - $505 \mathrm{~kg} / \mathrm{ha}$ and Omsky 85 - $498 \mathrm{~kg} / \mathrm{ha}$ were distinguished at moderate amount. The same grades had the highest indicators at enhanced amount: 677, 675 and 614 $\mathrm{kg} / \mathrm{ha}$ respectively. The advantage of enhanced amount was demonstrated by the increase in the protein yield per hectare of the studied grades by $34-170 \mathrm{~kg} / \mathrm{ha}$
TABLE I. $\quad$ PROTEIN CONTENT IN BARLEY GRAINS, \% (2011-2013)

\begin{tabular}{|l|c|c|c|c|}
\hline \multirow{2}{*}{ Grade } & \multicolumn{2}{|c|}{ Protein content, \% } & \multicolumn{2}{c|}{ Protein yield, kg/ha } \\
\cline { 2 - 5 } & $\begin{array}{c}\text { moderate } \\
\text { amount }\end{array}$ & $\begin{array}{c}\text { enhanced } \\
\text { amount }\end{array}$ & $\begin{array}{c}\text { moderate } \\
\text { amount }\end{array}$ & $\begin{array}{c}\text { enhanced } \\
\text { amount }\end{array}$ \\
\hline Acha & $\begin{array}{c}9.93 \pm \\
0.53^{*}\end{array}$ & $12.29 \pm 0.49$ & $505 \pm 66$ & $675 \pm 41$ \\
\hline Omsky 85 & $8.62 \pm 0.43$ & $10.28 \pm 0.51$ & $498 \pm 5$ & $614 \pm 31$ \\
\hline Peydzhaz & $8.76 \pm 0.42$ & $9.75 \pm 0.19$ & $474 \pm 32$ & $542 \pm 18$ \\
\hline Baltika & $9.09 \pm 0.23$ & $9.93 \pm 0.42$ & $410 \pm 2$ & $444 \pm 3$ \\
\hline Jana & $8.89 \pm 0.20$ & $10.17 \pm 0.31$ & $435 \pm 10$ & $487 \pm 6$ \\
\hline Beatrice & $9.53 \pm 0.02$ & $11.57 \pm 0.20$ & $529 \pm 1$ & $677 \pm 16$ \\
\hline
\end{tabular}

* deviation from average throughout the years of study $\left(\mathrm{S}_{\mathrm{x}}\right)$

According to experiment 2, which included the treatment of barley seeds and plants with microfertilizers, the productivity of the Acha grade throughout the years of study made on average $4.17 \mathrm{t} / \mathrm{ha}$ at the control stage (Fig. 2).

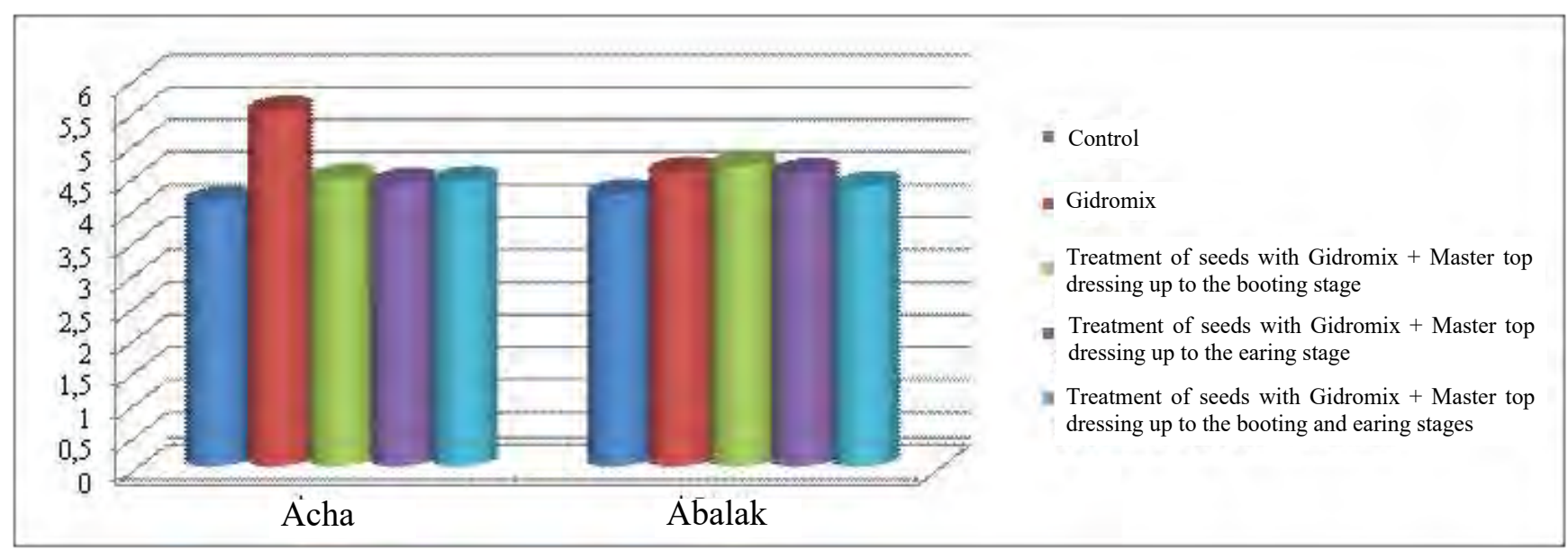

Fig. 2. Productivity of barley grades treated with microfertilizers, t/ha (2014-2016) 
Additional yield ranging from 0.28 to $0.38 \mathrm{t} / \mathrm{ha}$ was obtained for all studied options. The Acha grade showed the highest productivity through seeds treatment with Gidromix $(4.55 \mathrm{t} / \mathrm{ha})$ and through the option when seeds and plants were treated up to the booting stage $(4.52 \mathrm{t} / \mathrm{ha})$. The Abalak grade showed considerable increase through the implementation of the following options: $2(0.34 \mathrm{t} / \mathrm{ha}), 3(0.44 \mathrm{t} / \mathrm{ha})$ and $4(0.32$ $\mathrm{t} /$ ha) respectively. The Abalak grade showed the highest productivity through the treatment of seeds with Gidromix and plants - with the Master complex up to the booting stage (4.72 t/ha).

The protein content in the Acha grade varied from 11.93 to $13.5 \%$ (Tab. 2). Microfertilizers produced an increasing effect by $1.14 ; 1.29 ; 1.44 ; 1.57 \%$ for experiment options respectively. The highest protein content was recorded in option 5 with the treatment of seeds and dual treatment of plants (13.5\%). The protein content of the Abalak grade varied to a lesser extent than that of the Acha grade - from 12.74 to $13.54 \%$. The use of microfertilizers contributed to the increase of the indicator by $0.53 ; 0.50 ; 0.68 ; 0.80 \%$ respectively.

Thus, it is possible to note the growing tendency of protein content in barley grains treated with microfertilizers.

The protein yield per hectare of barley grades is much higher in options with the use of microfertilizers (Tab. 2). The increase of the protein yield per hectare of the Acha grade for all options made respectively: $87 ; 87 ; 86 ; 99 \mathrm{~kg} / \mathrm{ha}$. The increase of the protein yield per hectare of the Abalak grade for all options made $68 ; 77 ; 74 ; 51 \mathrm{~kg} /$ ha respectively.

Hence, the use of microfertilizers for the treatment of barley seeds and plants ensured substantial increase of the protein yield per unit area.

According to experiment 3, which included the study of the influence of barley seed treatment with fungicides and growth regulators, it was found that the Abalak grade was more receptive than the Acha grade (Fig. 3). The maximum productivity of the Acha grade obtained through the treatment of seeds with Lamador fungicide and Rostok stimulator made $4.50 \mathrm{t} / \mathrm{ha}$, which is higher than that of the control stage by 0.37 $\mathrm{t} / \mathrm{ha}$. For the Abalak grade the productivity growth was obtained through the treatment of seeds with Rostok stimulator $(+0.27 \mathrm{t} / \mathrm{ha})$, Mival-Agro stimulator $(+0.45 \mathrm{t} / \mathrm{ha})$, Lamador Pro + Rostok (+0.40 t/ha), Lamador Pro + MivalAgro (+0.36 t/ha)

TABLE II. GRAIN PROTEIN CONTENT AND ITS YIELD PER UNIT AREA FOR BARLEY GRADES TREATED WITH MICROFERTILIZERS, 2014-2016

\begin{tabular}{|c|c|c|c|c|}
\hline \multirow{2}{*}{ Options } & \multicolumn{2}{|c|}{ Protein content, $\%$} & \multicolumn{2}{|c|}{ Protein yield, kg/ha } \\
\hline & Acha & Abalak & Acha & Abalak \\
\hline 1.Control & $11.93 \pm 0.59 *$ & $12.74 \pm 0.48$ & $507 \pm 18$ & $545 \pm 28$ \\
\hline $\begin{array}{l}\text { 2. Seed treatment } \\
\text { with Gidromix }\end{array}$ & $13.07 \pm 0.59$ & $13.27 \pm 0.65$ & $594 \pm 22$ & $613 \pm 30$ \\
\hline $\begin{array}{l}\text { 3. Treatment of } \\
\text { seeds with } \\
\text { Gidromix }+ \\
\text { Master top } \\
\text { dressing up to the } \\
\text { booting stage. }\end{array}$ & $13.22 \pm 0.68$ & $13.24 \pm 0.66$ & $594 \pm 43$ & $622 \pm 30$ \\
\hline $\begin{array}{l}\text { 4. Treatment of } \\
\text { seeds with } \\
\text { Gidromix }+ \\
\text { Master top } \\
\text { dressing up to the } \\
\text { earing stage. }\end{array}$ & $13.37 \pm 0.75$ & $13.42 \pm 0.66$ & $593 \pm 37$ & $619 \pm 24$ \\
\hline $\begin{array}{l}\text { 5. Treatment of } \\
\text { seeds with } \\
\text { Gidromix }+ \\
\text { Master top } \\
\text { dressing up to the } \\
\text { booting and } \\
\text { earing stages. }\end{array}$ & $13.50 \pm 0.68$ & $13.54 \pm 0.66$ & $606 \pm 31$ & $596 \pm 23$ \\
\hline
\end{tabular}

* deviation from average throughout the years of study $\left(\mathrm{S}_{\mathrm{x}}\right)$

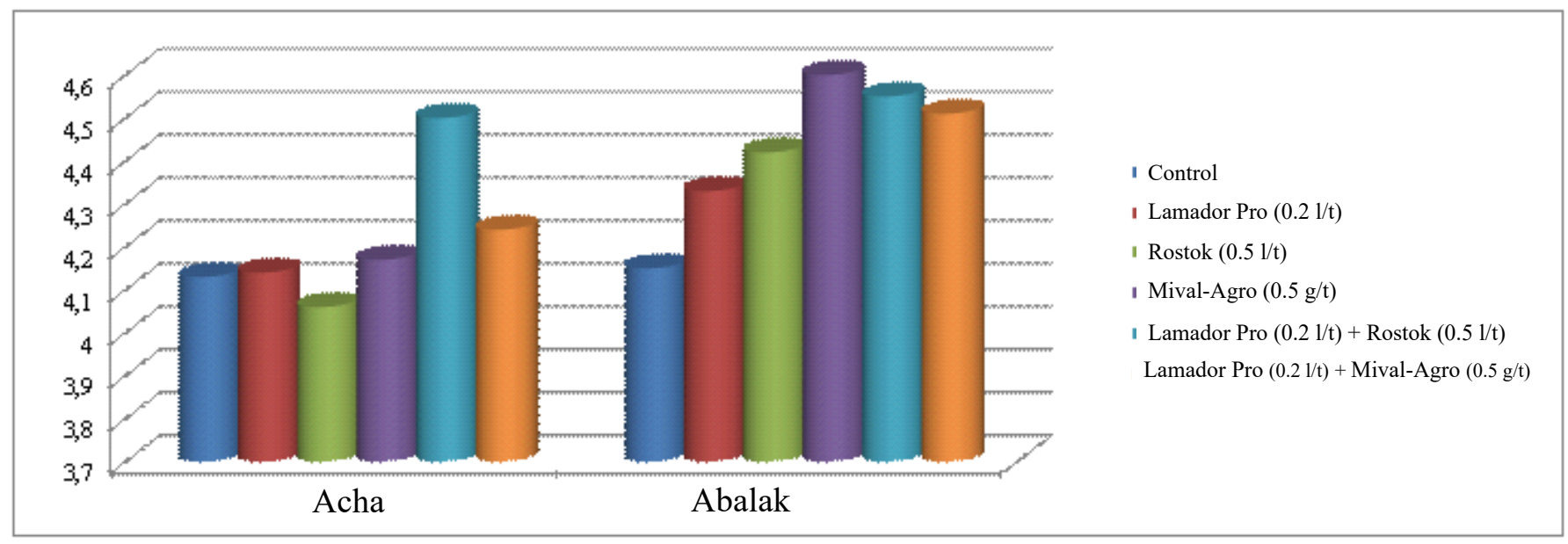

Fig. 3. Productivity of barley grades treated with fungicides and growth regulators, t/ha (2014-2016) 
The protein content in barley grains was quite high: Acha - 13.6-14.7\% and Abalak - 13.3-14.2\% (Tab. 3). Such level corresponds to P 53900-2010 GOST requirements to feeding barley of the first class.

TABLE III. GRAIN PROTEIN CONTENT AND ITS YIELD PER UNIT AREA FOR BARLEY GRADES TREATED WITH FUNGICIDES AND GROWTH REGULATORS, 2014-2016

\begin{tabular}{|l|c|c|c|c|}
\hline \multirow{2}{*}{ Options } & \multicolumn{2}{|c|}{ Protein content, \% } & \multicolumn{2}{c|}{ Protein yield, kg/ha } \\
\cline { 2 - 5 } & Acha & Abalak & Acha & Abalak \\
\hline 1. Control & $13.73 \pm 0.46^{*}$ & $13.31 \pm 0.42$ & $565 \pm 16$ & $552 \pm 37$ \\
\hline 2. Lamador Pro (0.2 1/t) & $14.66 \pm 0.44$ & $14.17 \pm 0.31$ & $608 \pm 44$ & $614 \pm 60$ \\
\hline 3. Rostok (0.5 1/t) & $13.73 \pm 0.23$ & $13.88 \pm 0.23$ & $559 \pm 31$ & $616 \pm 35$ \\
\hline 4. Mival-Agro (5 g/t) & $13.52 \pm 0.14$ & $13.94 \pm 0.48$ & $565 \pm 19$ & $645 \pm 123$ \\
\hline $\begin{array}{l}\text { 5. Lamador Pro (0.2 1/t) } \\
\text { + Rostok (0.5 1/t) }\end{array}$ & $13.60 \pm 0.13$ & $14.17 \pm 0.45$ & $613 \pm 31$ & $647 \pm 90$ \\
\hline $\begin{array}{l}\text { 6. Lamador Pro (0.2 1/t) } \\
\text { + Mival-Agro (5 g/t) }\end{array}$ & $13.99 \pm 0.03$ & $13.53 \pm 0.62$ & $594 \pm 36$ & $622 \pm 59$ \\
\hline
\end{tabular}

* deviation from average throughout the years of study $\left(\mathrm{S}_{\mathrm{x}}\right)$

Regarding the protein yield per unit area of the Acha grade the following options showed the highest productivity growth: option 2 where seeds were treated with fungicides $(43 \mathrm{~kg} / \mathrm{ha}$ increase to control stage), option 5 where seeds were treated with Lamador Pro and Rostok (+48/kg/ha) and option 6 where seeds were treated with the tank mixture of fungicides and the Mival-Agro stimulator $(+29 \mathrm{~kg} / \mathrm{ha})$. The protein yield per unit area of the Abalak grade in all studied options was much higher than the control (by $62-95 \mathrm{~kg} / \mathrm{ha}$ ). The highest protein yield was noted in options where seeds were treated with Mival-Agro (645 kg/ha) and Lamador Pro + Rostok (647 $\mathrm{kg} / \mathrm{ha})$.

\section{CONCLUSIONS}

1. Omsky 85 and Beatrice grades were marked as having the highest productivity during the study of malting barley varieties in the northern forest-steppe area of Tyumen region. At a moderate amount the productivity of these grades made 5.78 and $5.55 \mathrm{t} / \mathrm{ha}$, at enhanced -5.98 and $5.84 \mathrm{t} / \mathrm{ha}$ respectively.

The protein content in the studied grades corresponded to GOST requirements of malting barley.

2. The treatment of seeds and plants of barley grades with microfertilizers contributed to the productivity growth. The Acha grade showed the highest productivity when the seeds were treated with Gidromix (4.55 t/ha), and the Abalak grade - when seeds were treated with Gidromix and plants with the Master complex up to the booting stage $(4.72 \mathrm{t} / \mathrm{ha})$. The use of microfertilizers ensured substantial increase of protein yield per unit area.

3. As a result of studying the influence of barley seed treatment with fungicides and growth regulators it was found that the Abalak grade was more receptive than the Acha grade. The Acha grade showed the maximum productivity when seeds were treated with Lamador fungicide and Rostok stimulator - $4.50 \mathrm{t} / \mathrm{ha}$, and the Abalak grade - when seeds were treated with Mival-Agro stimulator $-4.60 \mathrm{t} / \mathrm{ha}$. The protein content in barley grains was quite high $-13.2-14.7 \%$, which corresponds to the P 53900-2010 GOST requirements to feeding barley of the first class.

\section{References}

[1] P. Atanassov, M. Zaharieva, O. Merah, P. Monneveux, Genetic and environmental variation useful traits in a collection of naked barley. II. Yield components and water efficiency, Cereal Res. Commun, 1999a, V. 27, No. 3, pp. 315-322.

[2] A.A. Gryaznov, Hulless barley in pig feeding, Questions of standard and legal regulation in veterinary science, No. 2, 2015, pp. 289-291.

[3] I.V. Opanasyuk, Quality of malting barley variety grains in Northern Trans-Ural region,Agrarian bulletin of the Urals, 2012, No. 2, pp. 1315 .

[4] R.I. Belkina, M.V. Gubanov, A.A. Gryaznov, V.M. Gubanova, Quality of chaffy and hulless barley grains in Northern Trans-Ural region, Agrofood policy of Russia, 2015, No. 10 (46), pp. 22-25.

[5] Yu.P. Loginov, A.A. Kazak, L.I. Yakubyshina, Commercial barley resources in Western Siberia, Agrarian bulletin of the Urals, 2012, No. 7(99), pp. 8-10.

[6] Yu.P. Loginov, A.A. Kazak, L.I. Yakubyshina, Polytypic barley varieties in Siberia, Agrofood policy of Russia, 2015, No. 9 (45), pp. 50-54.

[7] M.V. Gubanov, The study of chaffy barley in northern forest-steppe area of Tyumen region, Messenger of Krasnoyarsk State Agricultural University, 2015, No. 2, pp. 108-112.

[8] L.I. Yakubyshina, N.A. Neshumayeva, A.V. Sidorov, Creation of new barley varieties for forage, Messenger of Krasnoyarsk State Agricultural University, 2016, No. 2 (113), pp. 148-152.

[9] Yu.P. Loginov, A.A. Kazak, L.I. Yakubyshina., Import substitution of grain crops in Tyumen region, Barley varieties in Western Siberia, Agrarian bulletin of the Urals, 2012, No. 7(99), pp. 8-10.

[10] V.E. Torikov, O.V. Melnikova, A.A. Bakayev Influence of cultivation conditions on productivity of summer barley, Messenger of Bryansk State Agricultural Academy, 2009, No. 3, pp. 38-43.

[11] S.D. Karakotov, A.D. Denisov, Micro- and organo-mineral fertilizers for pre-sowing treatment of seeds, soil and foliar dressing of crops, SHCHYOLKOVO AGROKHIM, 2014, pp. 84.

[12] E.Yu. Geyger, L.D. Varlamova, V.V. Semyonov, Yu.V. Pogodina, Yu.A. Sirotina, Chelate-based microfertilizers: experience and prospects, Agrochemical messenger, 2017, No. 2, pp. 23-26.

[13] A.A. Savchenko, R.I. Belkina, A.N. Utkin, Use of microfertilizers growth regulators and fungicides in cultivation technology of summer wheat, Tyumen: TSAA, 2012, pp. 142.

[14] A.B. Laptiyev, O.V. Kungurtseva, New medicines for protection of summer grain crops against seed and soil infection, Protection and quarantine of plants, 2016, No. 2, pp. 20-23.

[15] V.V. Nemchenko, A.Yu. Kekalo, N.Yu. Zargaryan, M.Yu. Tsypysheva, Seed treatment - first step in production, protection and agrocoenosis, Protection and quarantine of plants, 2014, No. 3, pp. 2224.

[16] E.Yu. Toropova, A.F. Zakharov, Seedbed treatment of summer wheat in the conditions of resource-saving technologies, Protection and quarantine of plants, 2017, No. 3, pp. 28-31. 